\title{
Competencies for Production, Search, Diffusion and Mobilization of Open Educational Resources
}

\author{
Ramona-Imelda García-López ${ }^{1}$, Omar Cuevas Salazar², María-Soledad Ramírez-Montoya ${ }^{3}$ \& \\ Gloria-Concepción Tenorio-Sepúlveda ${ }^{4}$ \\ ${ }^{1}$ Education Department, Technological Institute of Sonora, Mexico \\ ${ }^{2}$ Mathematics Department, Technological Institute of Sonora, Mexico \\ ${ }^{3}$ Technological of Monterrey, Mexico \\ ${ }^{4}$ Technological of Chalco, Mexico \\ Correspondence: Ramona-Imelda García-López, 5 de Febrero \#818 sur. Col. Centro. C.P. 85000. Cd. Obregón, \\ Sonora, Mexico. Tel: 52-644-410-0900. E-mail: igarcia@itson.edu.mx
}

Received: September 18, 2016

doi:10.5539/ies.v10n4p78
Accepted: November 2, 2016

Online Published: March 30, 2017

* Academic institutions participating: Tecnológico de Monterrey, Instituto Tecnológico de Sonora, Tecnológico de Estudios Superiores de Chalco, Universidad de Montemorelos, Universidad Autónoma de Yucatán, Universidad de Guadalajara, Escuela Normal Superior Oficial de Guanajuato, Instituto Tecnológico de Chihuahua, Universidad Autónoma de Baja California y Universidad Autónoma del Estado de México.

\begin{abstract}
The purpose of this study is to evaluate the achievement of competencies for production, search, diffusion and open educational resources through a Massive Open Online Course (MOOC). The development of this project required the participation of 10 institutions of higher education in Mexico*, as well as financial support from the National System of Distance Education (SINED). This is a quantitative research and the participants were 134 teachers in Mexico and other Latin American countries. Rubrics were used to evaluate the competencies mentioned (which conformed the four modules object of study); each was broken down into indicators and self-assessment was used with the student (basic), beginner (intermediate) and expert (advanced) criteria. It was found that in the three levels of competency, the total percentage is very similar in the four modules: Basic level is between $0.5 \%$ y $3.9 \%$, intermediate, around $30.0 \%$ and $31.5 \%$ and advanced around $65.4 \%$ and $69.5 \%$.
\end{abstract}

Keywords: assessment, competencies, MOOC, open educational movement, open educational resources

\section{Introduction}

Information and Communication Technologies (ICT) are the basis for innovation. However, they fail to improve on society's ability to develop a knowledge-based economy on their own. In a digital economy, resources depend on the ability to connect and promote knowledge. Open online courses develop competencies to participate in a digital economy, improving collaboration skills among peers and abilities for the production of digital resources. The massive open online courses (MOOC) can be useful for the development of participatory practices that social media favor.

A MOOC can be defined as a complex system that seeks out new ways of interpreting the world's phenomena. These courses feature common characteristics including: massive participation, open online access, readings in short video format combined with formative assessments; automatic evaluation and/or peer assessment and online self-assessment. Its main feature is that activities are online, which gives learners flexibility for accessing course's materials anytime, anywhere. Is a free registry online course, with shared curricula and open results; they are facilitated by leaders in the field of study and are constructed from the students' compromise who self-organize their participations according to their learning goals, knowledge and previous skills and interests (MacAuley, Stewart, Siemens, \& Cormier, 2010).

The pedagogical problems, challenges and questions about MOOC include: 1) the conditions under which successful participation may extend beyond those with broadband access and sophisticated digital skills; 2) 
identifying the processes and practices that can motivate participants to take a more active central role; 3 ) strategies to maximize the facilitators effective contribution as well as the more advanced participants; and 4) the accreditation role, if there is one, and how can it be implemented. It is necessary to determine the design elements of the MOOC to maximize their self-organization, self-reference and knowledge production capabilities. There is a need for further research so the scientific community can redesign the framework in which emerging technologies enrich institutes and educational practices (deWaard et al., 2011; MacAuley et al., 2010).

The use of social media is central and enables connectivity, communication and interaction among participants asynchronously and synchronously; thanks to them, learners can overcome time and space. The MOOC fits the current context of students, allowing the construction of knowledge and promoting development of various skills (Glance, Forsey, \& Riley, 2013; deWaard et al., 2011; Canto, Méndez, Ramírez, \& Quiñonez, 2014).

A MOOC integrates the connectivity of social networks, the ease of expert knowledge in the field of study, and a free access collection of online resources. Furthermore, students self-organize their participation according to their learning goals, previous knowledge and abilities, and common interests. Although it shares some of the conventions of traditional courses, like predefined time and weekly topics for their considerations, it usually has no cost, no prerequisites, no predefined expectations nor formal accreditation.

User-generated content initiatives, the increase of open educational practices, and the MOOC are transforming concise scenarios in others of uncertain nature. Learning is increasingly casual as people develop complex networks to support each other. It is expected that in the future, educational institutions and lifelong learning facilitators encourage and support open educational practices; which aid in training teachers, students and workers in the competencies, knowledge and skills to successfully participate in the knowledge society.

\subsection{Approaching the Problem}

There have been studies that show significant efforts at an international level regarding the issue of production and publication of educational resources and materials. However, the mobilization process of open knowledge in educational practices has been neglected. This process addresses the issue of transfer and/or appropriation of knowledge through open educational practices; these can be defined as activities supporting the use, reuse and production of open educational resources (OER) through institutional policies, promotion of innovative pedagogical models and empowering students as co-producers of their lifelong learning.

In 2012 a consultation was conducted over 50 universities in Latin America. This initiative was sponsored by the European Union. It allowed the generation of a series of strategic guidelines to promote openness in higher education to the design of policies and actions to maximize the use, reuse and remixing of OER for the development of university courses as a means to open access to knowledge (OportUnidad, 2012). This type of initiatives are important for they allow the identification of areas of common interest among educational institutions in Latin America, such as pedagogy, technology, organizational frameworks and new models of institutional funding and sustainability, including collaborative models among institutions and communities of interest.

On these grounds, the concern to develop a massive open online seminar arose, "Training online educators to develop OER skills". It is considered that this open education movement stimulates the development of open access activities; fosters the realization of formative practices, such as the use of OER available online, the production of open licensing materials, the selection of OER through connectors and repositories, the spread of practices in different settings, and the mobilization towards educational practices.

Because of these reasons and considering the increasing importance of distance education environments, it is necessary to know: What skills are required to produce, search, select, diffuse and mobilize OER in open and distance learning? Moreover, how can these competencies be measured? From these questions it becomes important to create an assessment program that allows this measurement and thus identify areas of improvement within these competencies.

In this context, this research attempts to answer which are the perceptions of the participants in a MOOC, regarding the development of production, search, diffusion and mobilization of OER skills, and transfer them to a distance education context.

An interdisciplinary team consisting of 10 institutions in the country was formed to respond these questions and support in the seminar's implementation. Moreover, for the realization of this research a funding from the National System of Distance Education (SINED) in Mexico was obtained. 


\subsection{Objective}

To assess the participants' competency level in a MOOC in regards to production, search, diffusion and mobilization of open educational resources in distance education environments, with the purpose of incorporating these resources and strengthening their development in educational practices.

\section{Theoretical Framework}

When change is continuous and expected, people commit to the learning process in order to increase their personal capital and maintain their commercial value and society is mobilized to improve its ability to create and negotiate knowledge. However, the fact of being interconnected is not enough to learn, it is necessary but not sufficient. People should know what they are learning and what competencies they are developing, as well as how they can demonstrate it and transfer it to their particular context. Access to digital information and social networks is not necessarily transformed into learning (Sangrá \& Wheeler, 2013).

Learners are open to a variety of nontraditional learning models nowadays; they are able to undertake their own learning outside the classroom structure. Although this has always been possible, students now have greater access to content and online opportunities. Open learning does not deny the role of the educator; they continue to play an important role in facilitating interaction, sharing information and resources, and contributing to learner's knowledge growth. Open courses are based on the participatory pedagogy model. The educator provides a frame for learning through starting-point readings and resources, with which learners are expected to actively contribute to the formation of the curriculum through conversations, discussions and interactions (Cormier \& Siemens, 2010).

A worldwide movement that promotes open access to digital resources, such as content and software tools is being developed to be used as a means to promote education and lifelong learning. This movement is part of a broader wave of initiatives that promote natural resources, public space and cultural heritage to be understood as a common good.

The term open educational resources (OER) has been introduced and promoted by UNESCO. It refers to the open provision of educational resources, permitted under information and communication technologies (ICT) for consultation, use and adaptation for non-commercial purposes. It is important to mention that resources are not limited to content, but they comprise three main areas of activity: the creation of open software and the development of tools, the creation and provision of the content for open courses, and the development of standards and licenses.

Open content has many authors, including professional authors, teachers and students, so it is in constant process of improvement. Although open means free of charge, it is by no means free of conditions; the nonprofit organization "Creative Commons", for instance, provides an easy to use mechanism for attaching one of the six standardized licenses to a document in which it can be requested that the product be shared with a similar license, that it is not used for commercial purposes, or that it requires attribution (Divenski, 2008; Downes, 2007).

OER has been the detonator for a very important change that could be considered as the formalization of informal learning. It is very common nowadays for universities to have a set of OER and to provide free access available for the use of all. There is no doubt that open access to resources is an important element in educational innovation; however, it does not solve all problems. It is clear that open content itself is not sufficient for effective lifelong learning. Before complying with useful educational content, tools, and licenses, pedagogical approaches should be considered. In which these resources could make a difference when used in innovative ways, in teaching and learning (Downes, 2007; Divenski, 2008; Sangrà \& Wheeler, 2013).

There is good acceptance by teachers in terms of design and use of OER. A study in an educational institution in Mexico showed that $84.6 \%$ of the participating teachers fully agreed, and $15.4 \%$ agreed with designing OER. $72 \%$ of the teachers who know the OER fully agree, while $28 \%$ agree that incorporating these types of resources is extremely necessary in their teaching practice (García, Cuevas, \& Angulo, 2013). There are institutions, even that are interested in training their students in the production of OER so that they participate in their innovative education projects; in this sense, a research carried out in a higher education institution shows it is feasible to include higher education students in the production of OER harnessing their ICT skills and instructing them in subjects like Copyright (Tenorio, 2013).

Teachers will not be simple end-users of OER because they will understand the importance of constant questioning, evaluation and improvement of educational practices and resources. As members of communities of interest in different disciplines and topics, they will share experiences, lessons learned and suggestions about how to promote the students development as well as their own skills and abilities (Divenski, 2008; Sangrà \& 
Wheeler, 2013).

On the other hand, the numerous courses initiatives from prestigious universities suggest that the content itself does not have enough value to build the future of higher education. The actions of institutions such as the Massachusetts Institute of Technology (MIT) suggest that the true benefit of the academy is the interaction and negotiation of knowledge. Unlike a structured course, open courses use materials from various sources, and conversations occur in several forms: blogs, Twitter, virtual worlds, among others. Open courses provide educators and learners the opportunity to develop skills, knowledge and mental states that are necessary to participate in the complex world situations.

Nowadays, the term competence is very common in many aspects of life, in fact there are multiple definitions. One of them is Beneitone's cited by Manriquez (2012, p. 370), who defines them as "abilities that every human being needs to solve, effectively and independently, the solutions of life. They are based on deep knowledge, not only to know what and how, but knowing how to be persons in a complex, changing and competitive world"; but competencies are not only the ability to carry out instructions also require something called performance, referring to this term as an added value by the competent, which allows him not only to apply instructions in isolation but to link them (Galvis, 2007).

The Economic Development and Cooperation Organization (OCDE) (2005) states that a competency is more than just knowledge and skills, it also requires facing complex demands involving attitudes in a particular context. They are attitudinal, whereby they are cognizable and sociable, but not equivalent to a mere skill or ability (Olivares, 2007). In this context, identifies key competencies for the challenges of today's world and classifies them into three broad categories: 1) use of tools to effectively interact with the environment. At this point encompassing physical and sociocultural aspects, as the use of language and information technology and communication; 2) interact with heterogeneous groups and 3) to act autonomously. Within the first category is the use of ICT, which is one of the skills that allow to free educators from repetitive, strictly informational tasks. Changing their role in the teaching-learning process, leading to the emergence of new roles as instructors, tutors, technological experts, administrators, documentalists, evaluators, document editors, among others (Tejada, 2000).

According to Argudín (2005), the concept of competence, as understood in education, results from the new theories of cognition and basically means performance knowledge. Since any process of "knowing" translates into "knowledge", then it is possible to say that competence and knowledge are reciprocal: knowing how to think, how to perform, how to interpret, how to act in different scenarios, from oneself and for everyone else (within a given context). In this manner, it is possible to say that competence in education is a convergence of social, affective behavior and cognitive, psychological, sensory and motor abilities that allow for adequately carrying out a role, a performance, an activity or task.

Competencies are an approach to education and not a pedagogical model, because they are not intended to be the ideal representation of an entire educational process. But it only focuses on some conceptual and methodological aspects of education and human talent management. For example: a) integration of different kinds of knowledge in the performance (knowing to be, knowing to do knowing to know and knowing to co-live); b) the construction of training programs in accordance with the institutional philosophy and disciplinary requirements; c) the orientation of education through quality standards in all its processes; d) emphasis on metacognition in teaching and skills assessment; e) the use of assessment strategies and instruments through the articulation of qualitative with quantitative (Tobón, 2008).

Assessment in the context of competency-based approach represents some advantages over traditional assessments. Some of them allow the inclusion of a wider range of attributes in its description, they publicly highlight what competent professionals should do and what is expected of them, they provide clearer goals for trainers and clarify expectations for learners. Similarly they provide basis for developing stronger professional skills assessment procedures and require clarification of what, why and how they will evaluate (Gonczi, 1994; Rivera, Bazaldúa, Rovira, Conde, \& Rodríguez, 2009, in Rueda (2009)).

On the other hand Cano (2008), in order to approach competence assessment, reference is made to two perspectives: the conception of assessment and the conception of competence. The following considerations are taken regarding the first:

- Barberá (2005) comments that assessment cannot be limited to scores (but that it is a subset of assessment); it cannot be focused on memory and repetition of information (but must assess higher order cognitive skills) and cannot be limited to pencil and paper tests, but that complex and varied instruments are required. 
- It constitutes a learning opportunity and it is not used for guessing or selecting those who possess certain competencies, but to encourage them in all students.

- Should be coherent with the rest of the elements in the formative design and be integrated in it.

- Must raise students' awareness of what their competence level is, of how they solve tasks, and of what strengths they should enhance and what weaknesses must be corrected to meet future learning situations.

However, one of the problems of competency assessment is that they are necessarily the product of a sequenced process; therefore it must include its domain, which can hardly be achieved through a single method. For that reason, different assessment instruments or strategies such as rubrics and portfolios are used. Rubrics are a sufficiently flexible resource that can be adjusted in practice to find the fair value of the evaluation. It has the property of a qualitative measuring descriptor instrument establishing criteria, standards and the nature of performance. Portfolios allow the teacher to apply a formative or process evaluation in an active and direct way, as an interactive process: student-portfolio-teacher. Which interaction and communication is based on student elaborated materials, allowing to detect strengths and weaknesses of the educational process evidenced.

Moreover, according to Fallas (2005) in regard to distance education, one of the mayor difficulties online course facilitators face is the need of having tools that allow them to objectively and consistently assess students' performance; in this sense, rubrics allow valuing learning, knowledge and competencies achieved by students in a particular task or activity by a gradation or quality levels through certain criteria; thus they are considered to be directly related to the so-called performance assessment; These can be expressed in terms of a scale: excellent, good, needs improvement, rookie, learner, expert, etc. or in numerical terms like 4, 3, 2, 1 .

In this regard, Goodrich (2000) lists some reasons to use rubrics as assessment tools: a) they improve student performance, since these foster favorable conditions for learning; b) when used for self-assessment, greatly improve the ability to locate problems, and develop strategies to solve them; and c) when teachers evaluate the students work, projects, interventions, etc., they know clearly what determines the quality of these products.

In the new educational paradigm it is essential that the evaluation is an integral part of the process, providing useful information for students, teachers and institutions. Encouraging the discussion of the difficulties encountered in learning, in order to implement corrective action and being applied continuously throughout the whole process. In this regard, the assessment of learning must become a feedback tool that allows the student to have clear performance standards, which are expected in the different tasks, and discover specific aspects in which they should invest more effort.

\section{Method}

\subsection{Type of Study}

It is a quantitative descriptive study, since different instruments to assess the acquisition of skills in the development and implementation of OER in teaching practice were designed and analyzed as of the MOOC seminar development. In order to carry out the analysis of the findings, numerical variables were defined, which were treated by statistical methods.

The evaluated competencies are described in Table 1. It is worth mentioning that each of them is broken down into those main aspects that allowed for a better measurement. These competencies were defined in function of the contents that were implemented in the MOOC that was designed as a tool to develop the abilities of production, search and selection, diffusion and appropriation of the open educational resources (Burgos \& Ramírez, 2011).

The content was developed according to the UNESCO (2011) guidelines when concerning the competencies required in the current society of knowledge for the effective use of ICT in the educational environment

Table 1. Competencies object of study

\begin{tabular}{ll}
\hline COMPETENCY & DEFINITION \\
\hline Module I. Competencies for the production of OER & \\
\hline Creative thinking (innovation) & $\begin{array}{l}\text { Generation of divergent original ideas, to propose new } \\
\text { ways of doing things or solving problems. }\end{array}$ \\
\hline Digital literacy (use of ICT) & $\begin{array}{l}\text { Ability to identify the diverse ICT, knowing in which } \\
\text { context they can be used and applied. }\end{array}$ \\
\hline
\end{tabular}




\begin{tabular}{|c|c|}
\hline Multimedia management literacy & $\begin{array}{l}\text { Ability to access, comprehend and establish forms of } \\
\text { communication in a variety of contexts }\end{array}$ \\
\hline \multicolumn{2}{|l|}{ Module II. Competencies for the Search/Selection of OER } \\
\hline Information management literacy & $\begin{array}{l}\text { Ability to acquire timely, sufficient, useful and relatively } \\
\text { reliable information. }\end{array}$ \\
\hline English language and other languages management & $\begin{array}{l}\text { Ability to read, listen, write and speak English as an } \\
\text { essential requirement to access information. }\end{array}$ \\
\hline Learning on your own & $\begin{array}{l}\text { Ability to take action in autonomous self-directed and } \\
\text { self-regulated learning. }\end{array}$ \\
\hline \multicolumn{2}{|c|}{ Module III. Competencies for the diffusion of OERs (research) } \\
\hline Critical thinking & $\begin{array}{l}\text { Determining the degree of credibility certain information } \\
\text { has in terms of source and congruence. }\end{array}$ \\
\hline Scientific thinking in the context of sciences & $\begin{array}{l}\text { Solid reasoning based on abstract ideas, using methods } \\
\text { and techniques that allow for knowledge organization }\end{array}$ \\
\hline Work collaboratively (team work) & $\begin{array}{l}\text { Ability to interact and promote synergies with the } \\
\text { members of a group. }\end{array}$ \\
\hline Research-based learning & $\begin{array}{l}\text { Ability to make use of methods and techniques that allow } \\
\text { the accessible and scientific organization of knowledge. }\end{array}$ \\
\hline Online social behavior literacy (PLN, PLE) & $\begin{array}{l}\text { How people perform and relate with each other through } \\
\text { electronic virtual environments. }\end{array}$ \\
\hline \multicolumn{2}{|c|}{ Module IV. Competencies for mobilization (appropriation of OER) } \\
\hline Educational practice innovation & $\begin{array}{l}\text { Obtaining new knowledge through information } \\
\text { management, by recovery and processing of information. }\end{array}$ \\
\hline Posing and solving problems & $\begin{array}{l}\text { Ability to identify the initial and final states of a situation } \\
\text { and the procedures to overcome obstacles. }\end{array}$ \\
\hline Knowing how to communicate & $\begin{array}{l}\text { Ability to read, listen write and speak a language as } \\
\text { means to interact with people. }\end{array}$ \\
\hline
\end{tabular}

\subsection{Participants}

A total of 134 teachers participated in this study. They completed the seminar with all its activities. $68 \%$ of the participants are from Mexico, Argentina, Colombia, Ecuador, Uruguay, El Salvador and Venezuela. 35\% have a bachelor's degree, $52.2 \%$ master's degree, and $12.8 \% \mathrm{PhD}$. $68 \%$ fall into the category of professors, $7 \%$ managers, $7 \%$ students, and $6 \%$ into administrative. In terms of gender, $37.65 \%$ of the participants were male and $62.35 \%$ female.

\subsection{Instruments}

To evaluate the competencies defined in the seminar instructional design, several instruments were designed and applied at different stages of the process; in order to identify the achieved goals of the participants.

Foremost, a survey was designed to perform an inter-institutional diagnosis and identify the extent to which participants had been involved in the use of open educational resources (instrument 1). Afterwards, another self-diagnostic instrument was developed to determine the competencies regarding the open education movement (instrument 2). Later, the design of another questionnaire on competencies search and use of open educational resources (OER) was made (instrument 3). The appropriate rubrics were developed to assess the competencies under study and would be applied as self-assessment at the end of the Seminar (instrument 4). Four different rubrics were developed according to the defined competencies: 1) production, 2) search / selection, 3) research and 4) mobilization of OER, each one with the indicators as specified in Chart 1. In each of the rubrics the scale used was apprentice, practitioner and expert. Finally, a questionnaire was developed to assess the usability of the platform throughout the educational process (instrument 5).

It should be clarified that for this study only the features and results of instrument 4 are presented. This instrument underwent was a process of validity of content via the validation of experts, which means it was by consultant professors in the matter of the MOOC. The proposed modifications by the consultant professors were included in the final instrument.

\subsection{Procedure}

The instructional design of the seminar was developed with the participation of experts, both content and 
programmers. Once the competences were identified, various instruments that would allow to evaluate them throughout the process (diagnostic, formative and summative evaluation) were developed.

The MOOC was implemented during 4 weeks; at the end the rubrics were applied through self-assessment to determine the level of achievement of the competencies for each one of the participants. The data was collected on an electronic page and was processed utilizing Excel and SPSS. For the data analysis, Descripted Statistics was utilized, specifically graphs and frequency tables. Furthermore, Inferential Statistics, such as contingency tables to prove dependence between variables were used.

\section{Results}

The self-assessment survey consisting in 37 questions divided into four modules was applied and for its analysis frequency distributions, bar graphs, contingency charts and correlations were performed. For convenience, the results of the most significant questions of each of the modules and a chart that concentrates the results of the questions of the four modules are shown.

Module one questions were related to the competencies for the production of open educational resources. Table 2 shows the results of question 4 on the use of ICT for each of the three levels of study; $73.9 \%$ of the teachers dominate this competence efficiently; to $31.2 \%$ of the $\mathrm{PhD}$ teachers struggle using ICT, while $18.6 \%$ of the master's degree teachers and $29.2 \%$ of the bachelor's degree teachers are in the same level of competence. It can also be noted that only $2.2 \%$ of the teachers mentioned that require assistance to use ICT.

Table 2. Contingency chart showing the variables educational level and the level of competence on the use of ICT

\begin{tabular}{|c|c|c|c|c|c|}
\hline & \multicolumn{4}{|c|}{ Module 1 Question 4} & \multirow[t]{2}{*}{ Total } \\
\hline & & $\begin{array}{l}\text { I need help or } \\
\text { guidance to use } \\
\text { ICT }\end{array}$ & $\begin{array}{l}\text { Sometimes I } \\
\text { find it hard to } \\
\text { apply or use } \\
\text { ICTs }\end{array}$ & $\begin{array}{l}\text { I apply ICT } \\
\text { efficiently }\end{array}$ & \\
\hline \multirow{6}{*}{$\begin{array}{c}\text { Educational } \\
\text { Level }\end{array}$} & Bachelor's & 1 & 14 & 33 & 48 \\
\hline & Degree & $2.1 \%$ & $29.2 \%$ & $68.8 \%$ & $100 \%$ \\
\hline & Master's & 2 & 13 & 55 & 70 \\
\hline & Degree & $2.9 \%$ & $18.6 \%$ & $78.6 \%$ & $100 \%$ \\
\hline & \multirow{2}{*}{$\mathrm{PhD}$} & 0 & 5 & 11 & 16 \\
\hline & & $0.0 \%$ & $31.2 \%$ & $68.8 \%$ & $100 \%$ \\
\hline \multirow[t]{2}{*}{ Total } & & 3 & 32 & 99 & 134 \\
\hline & & $2.2 \%$ & $23.9 \%$ & $73.9 \%$ & $100 \%$ \\
\hline
\end{tabular}

For the contingency Table 2 the independence test was also made between the variables level of education and the competence of use of technology, obtaining a Chi-square of 2.67 with a value of $p=.61$, which is not significant, concluding with this that there is no dependence between the two variables.

In the sixth item in module one, it was questioned about the elements of OER as objective, strategy, purpose and audience; about that no teacher mentioned not being able to fully define these elements. At $27.1 \%$ of the bachelor's degree teachers; to $7.1 \%$ of the master's degree and $6.2 \%$ of the $\mathrm{PhD}$ found it difficult to define these elements; to $72.9 \%$ of the bachelor's degree teachers, master's degree at $92.9 \%$ and $93.8 \%$ from $\mathrm{PhD}$ found it easy defining these elements. The independence of the variables (level of education and competence on definition of elements) was also tested, obtaining a Chi-square of 10.24 with a value of $p=.006$, which is significant, thus there is dependence between the two variables. To determine whether this dependence between variables is linear, the Spearman's Rho correlation coefficient for nonparametric data was completed, obtaining a value of .258 , which is a very low dependency, thus can probe that the level of studies and the level of this competence is not linearly related.

In question seven module one, the characteristics of the OER as name, gender, presentation medium, granularity and type of open license were inquired; only $1.5 \%$ of the teachers failed to define any of these characteristics; $60.4 \%$ of the bachelor's degree teachers, $45.7 \%$ from master's degree and $25 \%$ of $\mathrm{PhD}$ were able to determine at least three of the characteristics; the $37.5 \%, 32.9 \%$ and $75 \%$ of the teachers of bachelors, masters and doctoral degrees respectively, easily determined all the characteristics. The test of independence between these variables 
was not significant with a Chi-square value of $=7.3$ and a $p$ value of $=0.121$, thus the variables are independent.

In module 2 the search and selection of the OER competence was defined and question five corresponded to communication in another language; $16.7 \%$ of bachelor's degree teachers mentioned that usually it is difficult to communicate in another language, while $22.9 \%$ of master's degree and none in $\mathrm{PhD}$ mentioned to be in this level of competence. In figure 1 the level of competence for the 134 participating teachers is exposed. As shown, only $17.9 \%$ of the teachers mention not to have problems communicating in another language. By analyzing these results it was obtained that the fact of providing material in Spanish was an important aspect that should be taken into consideration to design MOOC courses focused on Latin American participants (Ramirez, 2014).

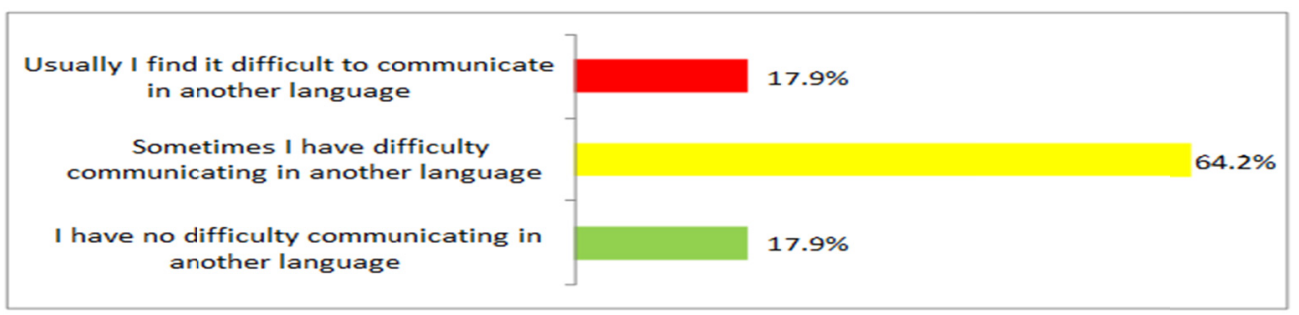

Figure 1. Competence level expressed regarding communication in another language

The independence of the variables (level of education and competence in communicating in another language) was also tested, resulting in a Chi-square of 12.97 with a value $p=.011$, which is significant $(\alpha=0.05)$, thus there is dependence between the two variables.

Question seven of module two, aimed to acknowledge the competence on the search of the OER. The $54.2 \%$ of bachelor's degree teachers declared to do it without problems, while $78.6 \%$ of the teachers with master's degree and $87.5 \%$ with doctorates are in the same level of competence. Figure 2 shows the percentage of each of the three levels of competence for all teachers.

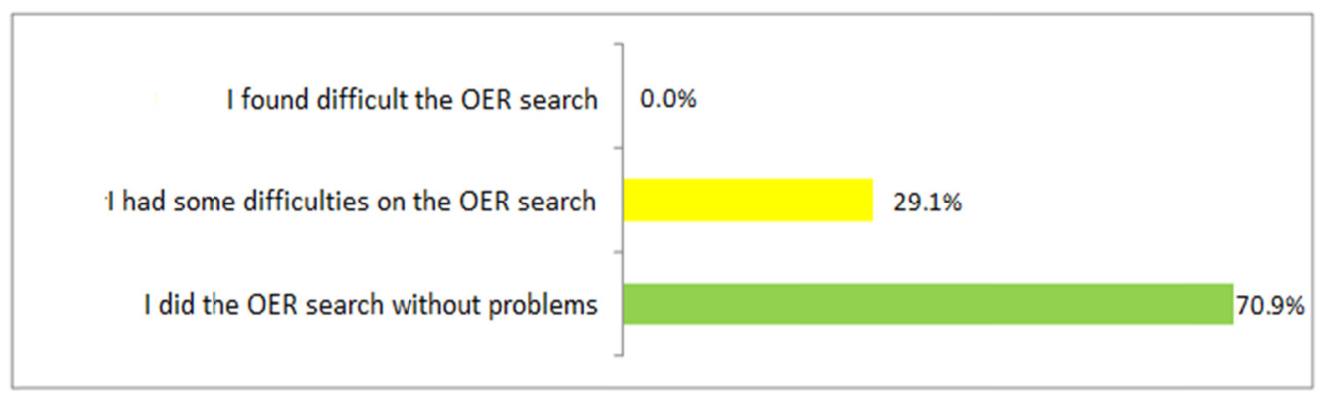

Figure 2. Level of competence participants expressed regarding the OER search

The independence test resulted with a Chi-square of 10.65 with a value $p=.001$, which is significant $(\alpha=0.05)$, thus there is dependence between the two variables.

In this regard, Gomez, Celaya, and Ramirez (2014) conducted a qualitative study on this competence and one of the results acquired was that participants did not found useful resources quickly that suited their needs and the seminar helped them to develop this competence. This was observed by the material included in their activities, which was adequate, relevant and specific.

Question eight of this same module, had to do with the integration of OER in teaching practice. The $9 \%$ of teachers expressed that they developed a work plan which included an instructional strategy for incorporating OER, $40.3 \%$ included two strategies and $50.7 \%$ involved three or more.

In module three competences for the diffusion of OER was defined. The tenth question was related to the design of strategies for the diffusion of OER; $27.6 \%$ of the teachers did it commonly at least in three of the elements, for example to whom it is addressed, with what purpose, how and with what means and $72.4 \%$ broadly defined each of the aspects mentioned. 
Question 11 corresponded to the results of implementing the OER diffusion strategy; $1.5 \%$ of the teachers defined in a general way where the OER were found and did not mention any improvements for the diffusion; $41.8 \%$ mentioned in a general manner the place where they found the OER and mentioned at least two improvements for the diffusion, meanwhile, $56.7 \%$ of the teachers defined precisely where they found the OER and declared at least two improvement for the diffusion.

Items in module 4 were related to competences to mobilize the OER. Question eight inquired about the communication through the media; $79.2 \%$ of the bachelor's degree teachers declared to fully establish communication processes through different media (e.g. audio, video, image and text); $65.7 \%$ of master's degree and $87.5 \%$ of $\mathrm{PhD}$ demonstrated in this same level of competence.

Tests of independence between the level of education and different competence for each of the 37 survey questions were performed. Only the three previously mentioned tests (module one question six, module two question five, and module two questions seven) were significant; dependence between the two variables was found. For the remaining 34 questions, independence between the variables (level of education and competence level) was found.

Finally, Table 3 shows the concentrate for each of the four modules by level of study and every level of competence, and the total for the entire survey sample. The level of competence was classified as basic, intermediate and advanced. Values represent percentages.

Table 3. Classification by level of competence by module and overall

\begin{tabular}{|c|c|c|c|c|}
\hline Modules & $\begin{array}{l}\text { Educational } \\
\text { Level }\end{array}$ & $\begin{array}{l}\text { Basic } \\
\text { Level }\end{array}$ & $\begin{array}{l}\text { Intermediate } \\
\text { Level }\end{array}$ & $\begin{array}{l}\text { Advanced } \\
\text { Level }\end{array}$ \\
\hline \multirow{4}{*}{ Module 1} & Bachelor's Degree & 0.6 & 37.2 & 62.2 \\
\hline & Master Degree & 2.2 & 28.6 & 69.2 \\
\hline & $\mathrm{PhD}$ & 0.0 & 27.7 & 72.3 \\
\hline & Total & 1.4 & 31.5 & 67.1 \\
\hline \multirow{4}{*}{ Module 2} & Bachelor's Degree & 2.6 & 37.8 & 59.6 \\
\hline & Master Degree & 4.6 & 27.0 & 68.4 \\
\hline & $\mathrm{PhD}$ & 0.8 & 20.3 & 78.9 \\
\hline & Total & 3.5 & 30.0 & 66.5 \\
\hline \multirow{4}{*}{ Module 3} & Bachelor's Degree & 0.9 & 30.9 & 68.2 \\
\hline & Master Degree & 0.3 & 32.1 & 67.6 \\
\hline & $\mathrm{PhD}$ & 0.0 & 18.8 & 81.2 \\
\hline & Total & 0.5 & 30.0 & 69.5 \\
\hline \multirow{4}{*}{ Module 4} & Bachelor's Degree & 3.8 & 33.1 & 63.1 \\
\hline & Master Degree & 4.3 & 31.8 & 63.9 \\
\hline & $\mathrm{PhD}$ & 0.6 & 18.2 & 81.2 \\
\hline & Total & 3.9 & 30.7 & 65.4 \\
\hline \multirow{4}{*}{ Survey } & Bachelor's Degree & 2.0 & 34.8 & 63.2 \\
\hline & Master Degree & 2.8 & 29.9 & 67.3 \\
\hline & $\mathrm{PhD}$ & 0.4 & 21.3 & 78.3 \\
\hline & Total & 2.3 & 30.6 & 67.1 \\
\hline
\end{tabular}

As shown in Table 3, a higher percentage of doctoral-level teachers have the advanced level in each of the four modules and $0.4 \%$ has the basic level in the entire survey. It is remarkable that in the three levels of competence the total percentage is very similar in all four modules; that is, the percentages at the basic level are between $0.5 \%$ and $3.9 \%$, in the intermediate range between $30.0 \%$ and $31.5 \%$, and in the advanced are between $65.4 \%$ and $69.5 \%$. From this it is concluded that the level of competence of teachers is very similar in the four modules that includes the survey.

\section{Discussion}

In assessing competences, as in the case of the required to learning, there is a need to distinguish cognitive, procedural and attitudinal level to approach them with appropriate forms of assessment. It is desirable that the assessment, by its very nature to point out the key issues and dot not arbitrarily impose a single way of 
responding to the challenges of educational practices (Rueda, 2009).

In the case of the level of performance of the various modules of the seminar it can be concluded that most of the participants were in the advanced or expert level, confirming the achievement of competence raised in the MOOC. Therefore, it is considered that the design of it contributed in some way in the formation of the participants in the use, selection, research and mobilization of the open educational resources and they would be considered as a means of support for the development of effective educational practices.

Furthermore, for the teacher to make adequate use of the open educational resources within their practice, it is important that in the production phase they make use of the competences implicated in the digital alphabetization, as to the utilization of technological tools, as well as to identify the principle elements that they compose to be able to be characterized adequately. For the search and selection of information its imperative to be capable of identifying materials in other languages (principally English) for this broadens the possibility to greater quantity of information, which would favor the elaboration of an educational resource of greater quality.

When it comes to the dissemination it is important to count with critical thinking that will allow you to determine the degree of credibility of the information, according to the source and its coherence; and to be able to use techniques and methods that will allow the organization of the knowledge in an accessible and scientific manner.

Finally, for the mobilization of the educational resources it is necessary to be able to communicate adequately orally and through the written word; efficient use of the methods of communication and to possess a creative mind capable of taking advantage of the resources and improving them.

Thus, in the context of distance education, a learner should be able to position his/her ideas in a way that others can see and understand. In addition facilitators need participants to build their own resources and share their opinions. The ability to work with digital tools to connect fragmented knowledge nodes is one of the most important competences in a MOOC. Develop their own knowledge and submit it through a coherent reflection, either through a $B \log$, mind maps, videos or other tools, requires a high level of digital literacy. Participants in a MOOC need to adapt themselves and overcome confusion and uncertainty greater than traditional courses, thus having an introductory understanding of the subject can be critical to their success. Having a basic digital literacy and familiarity with the subjects provides a point of orientation within the course (MacAulay, Stewart, \& Siemens, 2010).

Technical competences that form the basis for the participation include: download and install software; create podcasts; record, edit and upload files; create and share video; create and share mind maps; participate in discussions in communication forums synchronous and asynchronous; and capture important resources. Culturally, social competencies and the ability to expand our own cultural context are invaluable. Also, the competences related to productivity, taking stated positions, examine and criticize the work of others and challenge authority, are all critical to participation in a MOOC (MacAuley, Stewart, \& Siemens, 2010).

Above, it could be reflected in the contributions and reflections of all the participants, who to a greater or lesser extent, were able to apply their technical and digital competencies to achieve the objectives of each of the activities completed, enabling them to express a favorable mastery in production, research, selection, diffusion and mobilization of open educational resources to apply them in their teaching practice.

\section{Acknowledgments}

Special thanks to the authorities of National System of Distance Education and Latin American Community Open Regional of Social and Educational Research for provided financial, technological and infrastructure support for this project; in the same way to each of the research professors involved from the different academic organisms by the professional support in achieving the objectives of the study and preparation of the manuscript.

\section{References}

Argudín, Y. (2005). Competency-based education. Retrieved from http://educacion.jalisco.gob.mx/consulta/ educar/19/argudin.html

Barberá, E. (2005). Assessment of complex competencies: The practice of portfolio. Revista Educere. Artículos arbitrados, 9(31). 497-503. Retrieved from http://www.saber.ula.ve/bitstream/123456789/20005/2/articulo4. pdf

Burgos-Aguilar, J. V., \& Ramírez-Montoya, M. S. (2011). Innovative experiences of Open Educational Resources towards academic knowledge mobilization: Latin-American context. In Proceedings of OpenCourseWare Consortium Global 2011: Celebrating 10 Years of OpenCourseWare. Cambridge, MA. USA. Retrieved from: www.ruv.itesm.mx/convenio/catedra/recursos/material/ci_34.pdf 
Cano, M. E. (2008). Competency-based assessment in higher education. Retrieved from http://www.ugr.es/ recfpro/rev123COL1.pdf

Canto, P., Méndez, J., Ramírez, M. S., \& Quiñonez, S. H. (2014). Pedagogical design and assessment of a MOOC format seminar in Mexico. III Workshop Internacional sobre Creación de MOOC con anotaciones multimedia. Retrieved from http://gtea.uma.es/congresos/wp-content/uploads/2014/02/2.14.Comu_Comple. pdf

Cormier, D. \& Siemens, G. (2010). The Open Course: Through the Open Door-Open Courses as Research, Learning, and Engagement. Educause Review. 45(4), 30-39. Retrieved from http://er.educause.edu/ /media/files/article-downloads/erm1042.pdf

Dewaard, I., Abajian, S., Gallagher, M., Hogue, R., Keskin, N., Koutropoulos, A., \& Rodríguez, O. (2011). Using mLearning and MOOCs to understand chaos, emergence, and complexity in education. International Review of Research in Open and Distance Learning, 12 (7 Special issue), 94-115. Retrieved from: http://www.irrodl.org/index.php/irrodl/article/view/1046/2043

Divenski, D. (2008). Open educational resources and lifelong learning. Information Technology Interfaces, ITI 2008. 30th International Conference, 117-122. IEEE. https://doi.org/10.1109/ITI.2008.4588393

Downes, S. (2007). Models for sustainable open educational resources. Interdisciplinary Journal of Knowledge and Learning Objects, $3 . \quad$ Retrieved from http://www.cdlprojects.com/cmc11blog/wp-content/uploads/2011/07/IJKLOv3p029-044Downes1.pdf

Fallas, I. (2005). The use of assessment rubrics in online courses. Ponencia presentada en la Conferencia Internacional de Educación a Distancia, San Juan Puerto Rico. Retrieved from http://www.uned.ac.cr/ece/images/documents/documents2010/Articulo_de_Rubricas.pdf

Galvis, R. V. (2007). From a traditional teaching profile to a competency-based teaching profile. Acción pedagógica, 16, 48-57.

García, I., Cuevas, O. \& Angulo, J. (2013). Literacy in digital skills: Use of OER in the teaching practice. In M. S. Ramírez (Ed.), Competencias docentes y prácticas educativas abiertas en educación a distancia (pp. 10-23). México: Lulú editorial digital. Retrieved from http://catedra.ruv.itesm.mx/handle/987654321/745

Glance, D. G., Forsey, M., \& Riley, M. (2013). The pedagogical foundations of massive open online courses. First Monday, 18(5). https://doi.org/10.5210/fm.v18i5.4350

Gómez, M. L., Celaya, R., \& Ramírez, M. S. (2014). Design of self-study mutimedia for digital competencies: The case of the first Latin American MOOC. EDUTEC, Revista Electrónica de Tecnología Educativa, 47, 1-15. Retrieved from: http://catedra.ruv.itesm.mx/handle/987654321/831

Goodrich, H. (2000) Using Rubrics to Promote Thinking and Learning. Educational Leaderdship, 57(5).

MacAuley, A., Stewart, B., Siemens, G., \& Cormier, D. (2010). The MOOC model for digital practice. University of Prince Edward Island. Retrieved from http://www.elearnspace.org/Articles/MOOC_Final.pdf

Manríquez, L. (2012). Competency-based assessment? Estudios Pedagógicos, XXXVIII(1), 367-380.

OCDE. (2005). The definition and selection of key competencies. Retrieved from http://www.deseco.admin.ch/bfs/deseco/en/index/03/02.parsys.78532.downloadList.94248.DownloadFile.t $\mathrm{mp} / 2005$.dscexecutivesummary.sp.pdf

Olivares, A. (2007). Competencies for a knower world. Revista Interuniversitaria de Formación de Profesorado, 21(2-3), 137-148.

OportUnidad (2012). Agenda Regional de Prácticas Educativas Abiertas, OportUnidad project "Open educational practices: a bottom-up approach in Latin America and Europe to develop a common Higher Education Area". Iniciativa auspiciada por el programa de cooperación entre instituciones de educación superior de la Unión Europea y América Latina (ALFA III). Retrieved from http://oportunidadproject.eu/es/recursos/agenda-regional.html

Ramírez, M. S. (2014). Guidelines and success factors identified in the first MOOC in Latin America. Edulearn14. 6th International Conference on Education and New Learning Technologies (http://iated.org/edulearn/publications). Retrieved from http://catedra.ruv.itesm.mx/handle/987654321/840

Rueda, M. (2009). Evaluation of teaching performance: considerations from a competency-based approach. Retrieved from http://www.scielo.org.mx/scielo.php?pid=S160740412009000200005\&script=sci_arttext 
Sangrà, A. \& Wheeler, S. (2013). New ways of informal learning: or are we formalizing the informal? Revista De Universidad y Sociedad Del Conocimiento, 10(1), 107-115. https://doi.org/10.7238/rusc.v10i1.1689

Tenorio, G. C. (2013). OER production competencies in b-learning environments. In M. S. Ramírez (Ed.), Competencias docentes y prácticas educativas abiertas en educación a distancia (pp. 24-35). México: Lulú editorial digital. Retrieved from http://catedra.ruv.itesm.mx/handle/987654321/745

Tobón, S. (2008). Curricular management and propaedeutic cycles. Bogotá: ECOE

UNESCO. (2011). 1.3 Directrices para el Cuerpo Académico en Directrices para Recursos Educacionales Abiertos (REA) en la Educación Superior. Retrieved from http://wikieducator.org/Directrices_para_Recursos_Educacionales_Abiertos_en_la_Educaci\%C3\%B3n_Sup erior/Directrices_para_Tomadores_de_Decisiones_en_Educaci\%C3\%B3n_Superior\#Directrices_para_el_C uerpo_Acad.C3.A9mico

\section{Copyrights}

Copyright for this article is retained by the author(s), with first publication rights granted to the journal.

This is an open-access article distributed under the terms and conditions of the Creative Commons Attribution license (http://creativecommons.org/licenses/by/4.0/). 